\title{
ANALISIS KEEFEKTIFAN STRATEGI PEMBELAJARAN TRUE OR FALSE DAN TAKE AND GIVE TERHADAP HASIL BELAJAR SISWA PADA MATERI ASAM BASA KELAS XI SMA NEGERI 1 ALALAK
}

\author{
Effectiveness Analysis of True or False and Take and Give Learning \\ Strategy Towards Students' Learning Outcomes on Acid Base Topic Class \\ XI SMAN 1 Alalak
}

\author{
Siti Aisyah Nur Sari, Okviyoandra Akhyar, Raden Roro Ariessanty Alicia Kusuma \\ Wardhani \\ Program Studi Pendidikan Kimia Fakultas Keguruan dan Ilmu Pendidikan \\ Universitas Islam Kalimantan (Uniska) Muhammad Arsyad Al Banjari, Banjarmasin \\ *e-mail: sitiaisyahnursari976@gmail.com
}

\begin{abstract}
Abstrak.Penelitian ini bertujuan untuk mengetahui keefektifan strategi pembelajaran true or false dan take and give terhadap hasil belajar siswa pada pokok bahasan asam-basa kelas XI. Jenis penelitian ini adalah eksperimen menggunakan metode quasi eksperimen dengan rancangan "Non-equivalen Control Design" yang terdiri dari 2 kelas: kelas ekperimen I dan eksperimen II. Kelas eksperimen I mendapatkan perlakuan menggunakan pembelajaran aktif strategi true or false, sedangkan kelas eksperimen II menggunakan pembelajaran aktif strategi take and give. Tes dilakukan sebelum (pretest) dan sesudah perlakuan (postest). Teknik analasis yang digunakan adalahOne sample t-test.Hasil penelitianmenunjukkan: (1) Berdasarkan analisis nilai posttest denganOne sample t-test untuk kelas eksperimen I diperoleh nilai signifikansi sebesar $0,003<0,05$ hal ini berarti $\mathrm{H}_{0}$ ditolak artinya strategi true or false efektif dalam meningkatkan hasil belajar siswa. Pada kelas eksperimen II diperoleh nilai signifikansi sebesar $0,035<0,05$ berarti $\mathrm{H}_{0}$ ditolak artinya strategi take and give efektif dalam meningkatkan hasil belajar siswa,(2) efektivitas kelas ditinjau dari selisih hasil belajar pretest dan posttest menunjukkan pembelajaran menggunakan strategi true or false dengan presentase $30,59 \%$ lebih efektif daripada menggunakan take and give dengan presentase $21,33 \%$.
\end{abstract}

Kata Kunci: Hasil belajar, True or False, Take and Give

\begin{abstract}
This research aims to know the effectiveness of "True/False" and "Take \& Give"learning strategy towards learning result on acid base topic at class XI. The research type is experimental research using quasi experimental method with "Non-equivalent Control" design consisting of 2 classes: experiment class I and II. Experiment I class uses true or false strategy active learning, while experiment class II uses take and give strategyactive learning. The test is done before (pretest) and after treatment (postest). Data analytical technique used is one sample ttest.Research results show: (1)Based on the analysis of posttest value with One sample t-test for experimentclass I obtained significant value of $0.003<0.05$ this means $\mathrm{H}_{0}$ rejected means that true or false strategy is effective in improving student learning outcomes. In experiment class II obtained significant value of $0.035<0.05$ this means $H_{0}$ rejected means that take and give strategy is effective in improving student learning outcomes. (2)The class effectiveness gained
\end{abstract}


fromdifference between pretest and posttest learning result shows that learning using the true or false strategy with the percentage of 30,59\% is more effective than using take and give with the percentage of $21,33 \%$.

Keywords: Learning Outcomes, True or False, Take and Give

\section{PENDAHULUAN}

Pembelajaran adalah suatu sistem yang bertujuan untuk membantu proses belajar siswa, yang berisi serangkaian peristiwa yang dirancang, disusun sedemikian rupa untuk mempengaruhi dan mendukung terjadinya proses belajar siswa. Siswa sebagai subjek belajar harus berperan aktif dalam pembelajaran. Keaktifan siswa dinilai dari peranannya dalam pembelajaran, seperti bertanya, menjawab pertanyaan, memberi tanggapan dan lain-lain. Disamping itu, keaktifan siswa merupakan bentuk pembelajaran mandiri, yaitu siswa berusaha mempelajari segala sesuatu atas kehendak dan kemampuannya/usahanya sendiri, sehingga dalam hal ini guru hanya berperan sebagai pembimbing, motivator dan fasilitator. Oleh karena itu, guru perlu menciptakan suasana belajar yang dapat menumbuhkan sikap bekerjasama antara siswa satu dengan siswa lainnya(Sardiman, 2011).

Pembelajaran yang hanya menekan pada aspek kognitif semata dan kurang melibatkan siswa membuat siswa menjadi kurang mandiri dalam belajar bahkan cenderung pasif. Pemilihan dan penggunaan strategi belajar mengajar merupakan salah satu komponen dalam kegiatan belajar mengajar yang berperan membangun interaksi dan aktivitas belajar siswa dikelas. Perlunya adanya belajar aktif yang melibatkan siswa dalam semua proses pembelajaran, baik secara fisik maupun mental, meskipun pelaksanaannya belum bisa secara maksimal. Cara belajar aktif merupakan suatu proses belajar mengajar yang aktif dan dinamis. Pada prosesnya peserta didik mengalami keterlibatan intelektual dan emosional juga keterlibatan fisik. Keterlibatan fisik tersebut dalam proses pembelajaran secara intelektual-emosional dapat dijadikan suatu sistem yang efektif dan efisien sehingga tujuan pengajaran dapat tercapai dengan baik. Pada kegiatan belajar aktif tidak hanya membuat siswa lebih baik dalam menerima pelajaran juga membuat hasil belajar siswa menjadi lebih baik.

Permasalahan yang terjadi di SMA Negeri 1 Alalak adalah proses pembelajaran yang masih didominasi oleh guru. Berdasarkan wawancara dengan guru bidang studi kimia kelas XI, didapatkan informasi bahwa hasil belajar siswa pada pokok bahasan asam basa tahun ajaran 2015-2016 masih banyak yang berada dibawah Kriteria Ketuntasan Minimum (KKM). Berdasarkan keterangan guru, proses pembelajaran dimulai dengan menerangkan materi pelajaran, kemudian guru melakukan tanya jawab kepada siswa yang kemudian dilanjutkan dengan pemberian latihan. Apabila guru bertanya, hanya sebagian siswa saja yang aktif menjawab dan lebih didominasi oleh siswa tertentu saja. Pada saat mengerjakan latihan siswa cenderung mencontoh pekerjaan temannya, dan siswa yang tidak memiliki keberanian untuk menanyakan hal-hal yang tidak mereka pahami kepada guru. Berdasarkan observasi selama PPL 2 di SMA Negeri 1 Alalak, juga didapati bahwa siswa kurang aktif dan cenderung jenuh dalam proses pembelajaran.

Strategi yang bisa membuat siswa aktif adalah Strategi True of False dan Take and Give. Strategi True or False dan Take and Give adalah suatu strategi pembelajaran yang mengajak siswa untuk belajar aktif dan bertujuan agar dapat menumbuhkan daya 
kreatifitas dan mampu meningkatkan hasil belajar siswa. Penelitian yang dilakukan Arifah, dkk (2012) menyatakan bahwa penerapan strategi pembelajaran aktif true or false dapat meningkatkan hasil belajar siswa dan penelitian Antika, dkk (2013)menyatakan bahwa penerapan model pembelajaran kooperatif tipe Take and Give meningkatkan hasil belajar siswa secara signifikan dengan rata-rata $\mathrm{N}$-gain berkriteria sedang (0,5). Hal itu didukung dengan peningkatan aktivitas belajar siswa mengemukakan ide berkriteria sedang $(74,5 \%)$, bertukar informasi berkriteria tinggi $(84,3 \%)$, mengomunikasikan hasil diskusi berkriteria sangat tinggi $(90,2 \%)$, dan bertanya berkriteria sedang (74,5\%). Strategi True or False dan Take and Give mempunyai kelebihan masing-masing, diantaranya kelebihan dari strategi True or False adalah siswa dapat bekerjasama dengan siswa yang lain dalam hal pengetahuan dalam mengungkapkan alasan memilih jawaban benar dan memilih jawaban salah, sedangkan kelebihan Take and Give adalah siswa akan lebih cepat memahami penguasaan materi dan informasi karena mendapatkan informasi dari guru dan siswa lain serta dapat menghemat waktu. Strategi ini membolehkan peserta didik untuk berpasangan dan memainkan kuis dengan kawan sekelas dan mengembangkan sikap saling menghargai pendapat, dan siswa mampu mengelompokkan kata yang sama sehingga mudah dalam memahami materi pelajaran. Pemilihan strategi True or False dan Take and Give ini dikarenakan kesamaan kedua strategi ini yang menggunakan kartu. Penggunaan kartu lebih efektif dibandingkan game dari strategi yang lain, kondisi siswa yang banyak dan siswa kelas XI susah di atur maka strategi dengan menggunakan kartu siswa akan lebih terkontrol secara sikap.

Penggunaan strategi True or False dan Take and Give ini untuk membandingkan keefektifan antara strategi tersebut dalam meningkatkan hasil belajar siswa. Dengan melihat permasalahan pada SMA Negeri 1 Alalak, peneliti meneliti tentang Analisis Keefektifan Strategi Pembelajaran True Or False dan Take and Give Terhadap Hasil Belajar Siswa Pada Materi Asam Basa Kelas XI SMA Negeri 1 Alalak.

Berdasarkan permasalahan di atas, dirumuskan masalah penelitian ini berupa; (1) Apakah pengunaan strategi pembelajaran true or false efektif dalam meningkatkan hasil belajar siswa pada pokok bahasan asam basa? (2) Apakah penggunaan strategi pembelajaran take and give efektif dalam meningkatkan hasil belajar siswa pada pokok bahasan asam basa? (3) Manakah yang lebih efektif antara pengunaan strategi pembelajaran true or false dan strategi pembelajaran take and give terhadap meningkat hasil belajar siswa pada pokok bahasan asam basa.

Adapun tujuan dalam penelitian ini adalah untuk (1) mengetahui keefektifan strategi pembelajaran true or false dalam meningkatkan hasil belajar siswa pada pokok bahasan asam basa. (2) mengetahui keefektifan strategi pembelajaran take and give dalam meningkatkan hasil belajar siswa pada pokok bahasan asam basa. (3) mengetahui lebih efektif pengunaan strategi pembelajaran true or false atau strategi pembelajaran take and give terhadap meningkat hasil belajar siswa pada pokok bahasan asam basa.

Strategi pembelajaran dikembangkan atau diturunkan dari model pembelajaran. Dari beberapa pengertian di atas, strategi pembelajaran meliputi rencana, metode, dan perangkat kegiatan yang direncakan untuk mencapai tujuan pengajaran tertentu. Untuk melaksanakan strategi tertentu diperlukan seperangkat metode pengajaran(Majid, 2013). Pada proses belajar mengajar sangat diperlukan suatu strategi yang dapat membantu dalam menyampaikan suatu materi pembelajaran dengan baik. Seorang pengajar 
menggunakan pembelajaran aktif agar siswa bisa turut serta dalam pembelajaran. Pada penerapan suatu strategi harus disesuiakan dengan materi yang akan disampaikan.

Langkah-langkah pembelajaran dalam strategi pembelajaran aktif tipe true or false akan mengaktifkan siswa sejak awal pembelajaran yang akan merangsang siswa untuk berfikir dan memotivasi siswa untuk berperan aktif dalam aktifitas belajar sehingga guru tidak terlalu mendominasi proses pembelajaran. Strategi ini ditandai dengan guru membuat pernyataan-pernyataan yang sesuai dengan materi pelajaran, ada yang benar dan ada yang salah. Kemudian siswa berdiskusi dalam kelompoknya untuk menyatakan apakah pernyataan tersebut benar atau salah. Dengan berdiskusi siswa dapat saling bertukar pendapat. Menurut Silberman(2011)dengan mendengarkan beragam pendapat, siswa akan tertantang untuk berfikir.

Langkah-langkah dalam strategi take and give; (1) Guru menyiapkan kelas sebagaimana mestinya. (2) Guru menjelaskan materi sesuai kompetensi yang sudah direncanakan selama 45 menit. (3) Untuk memantapkan penguasaaan siswa akan materi yang dijelaskan, setiap siswa diberikan satu kartu untuk dipelajari selama 5 menit. (4) Kemudian Guru meminta semua siswa berdiri dan mencari teman pasangan untuk menginformasikan materi yang telah diterimannya. (5) Tiap siswa harus mencatat nama teman pasangannya pada kartu yang sudah diberikan. (6) Demikian seterusnya sampai semua siswa salling memberi dan menerima materi (Take and Give). (7) Guru mengevaluasi keberhasian model pembelajaran Take and Give dengan memberi siswa pertanyaan yang tidak sesuai dengan kartunya (kartu orang lain). (8) Guru dan siswa membuat kesimpuan bersama mengenai materi pelajaran. (9) Guru menutup pelajaran.

Perangkat pembelajaran adalah perlengkapan proses belajar mengajar yang terdiri dari silabus dan RPP. Perangkat pembelajaran pada penelitian ini meliputi : Silabus, RPP, dan buku ajarsiswa. Dalam penelitian ini , hipotesis dari peneliti adalah,; (1) Hipotesis 1, Ho1: Strategi True or False tidak efektif dalam meningkatkan hasil belajar siswa. Ha1: Strategi True or False efektif dalam meningkatkan hasil belajar siswa. (2) Hipotesis 2, Ho2: Strategi Take and Give tidak efektif dalam meningkatkan hasil belajar siswa. Ha2: Strategi Take and Give efektif dalam meningkatkan hasil belajar siswa. (3) Hipotesis 3, Ho3:Tidak terdapat strategi yang lebih efektif dalam meningkatkan hasil belajar siswa. Ha3:Terdapat salah satu strategi efektif dalam meningkatkan hasil belajar siswa.

\section{METODE PENELITIAN}

Jenis penelitian ini adalah penelitian eksperimen yang mana bertujuan untuk mengetahui pengaruh pembelajaran aktif dalam suatu kegiatan belajar mengajar di kelas terhadap perbedaan hasil belajar siswa. hasilnya dapat dilihat dari perbedaan hasil belajar siswa antara pembelajaran aktif dengan menggunakan strategi True or Falsedibandingkan dengan pembelajaran aktif menggunakan strategi Indek Card Macth pada materi asam basa. Subyek dalam penelitian ini adalah siswa kelas XI IA di SMA Negeri 1 Alalak.Pada penelitian ini kelas XI IA-2 sebagaikelaseksperimen I dankelas XI IA-3 sebagaikelaseksperimen II.

Metode yang akan digunakan adalah metode penelitian eksperimen semu (Quasi Experimental Design) dengan desain Non equivalent control Group design dimana kelompok eksperimen maupun kelompok kontrol tidak dipilih secara random. Data diambil melalui Pre test dan post test yaitu cara memberikan Pre test sebelum diberi 
perlakuan dan post test (tes akhir) setelah memberikan perlakuan. Mekanisme penelitian dari kedua kelas tersebut digambarkan pada gambar sebagai berikut :

\begin{tabular}{lrrr}
\hline Kelas & Pre-Test & Treatment & Pos-Test \\
\hline Eksperimen I & $\mathrm{O}_{1}$ & $\mathrm{X}_{1}$ & $\mathrm{O}_{2}$ \\
Kontrol & $\mathrm{O}_{3}$ & $\mathrm{X}_{2}$ & $\mathrm{O}_{4}$ \\
\hline
\end{tabular}

(Sugiyono, 2012, p. 116)

Keterangan :

$\mathrm{X}_{1} \quad$ : Perlakuan (Pembelajaranmenggunakanstrategipembelajaran True or False)

$\mathrm{X}_{2} \quad$ : Perlakuan (Pembelajaranmenggunakanstrategipembelajaran Take and Give)

$\mathrm{O}_{1} \& \mathrm{O}_{3}$ : Pre-test yaitusoaltes yang diberikankepadasiswasebelumdiberiperlakuan

$\mathrm{O}_{2} \& \mathrm{O}_{4}$ : Postestyaitusoaltes yang diberikankepadasiswasetelahdiberiperlakuan

Pada penelitian ini teknik yang digunakan adalah teknik observasi (pengamatan). Dengan teknik ini ,dapat dilihat bagaimana perkembangan hasil belajar siswa untuk mengetahui pengaruh pembelajaran aktif strategi True or False dengan strategi Index Card Match terhadap hasil belajar. Digunakan untuk untuk mengetahui aktivitas siswa terhadap pembelajaran yang menggunakan pembelajaran aktif strategi The Firing Line dengan pembelajaran aktif strategi Indeks Card Match

Instrumen penelitian adalah alat atau fasilitas yang digunakan oleh peneliti dalam rangka mengumpulkan data agar pekerjaannya lebih mudah dan hasilnya lebih baik, dalam arti lebih cermat, lengkap, dan sistematis sehingga lebih mudah diolah. Instrumen penelitian yang digunakan dalam penelitian ini adalah lembar tes soal Pre test dan Posttest, RPP, Silabus, dan lembar aktivitas belajar

Analisis data meliputi analisis butir soal dan analisis hasil belajar siswa. Analisis butir soal dilakukan dengan menggunakan software Anates V4. Pada penelitian ini, analisis butir soal digunakan untuk mengetahui validitas butir soal, reliabilitas, taraf kesukaran, dan daya beda butir soal. Sedangkan untuk hasil belajar siswa, data yang diperoleh di analisis uji normalitas, uji Homogenitas serta analisis data menggunakan One sample t test.

\section{HASIL DAN PEMBAHASAN}

Analisis Butir Soal

1. Pengujian validitas butir soal

Dalam penelitian ini dilakukan perhitungan validitas butir soal dengan menggunakan AnatesV4. Hasil dari perhitungan sebagai berikut:

Tabel 1. Hasil Analisis Validitas Butir Soal

\begin{tabular}{llc}
\hline Kriteria & No. Butir Soal & Jumlah \\
\hline Valid & $1,3,6,9,13,16,20,28,29,30,35$ & 11 \\
Tidak Valid & $2,4,5,7,8,10,11,12,14,15,17,18,19,21,22,23$, & 24 \\
& $24,25,26,27,31,32,33,34$ & \\
\hline
\end{tabular}


Setelah pengujian validitas butir soal menggunakan AnatesV4, soal tersebut menjadi 11 soal yang valid dan dapat digunakan, dan dari 11 soal yang dapat digunakan ini, akan di jadikan soal Pre-test dan Post-test siswa.

\section{Pengujian Reliabilitas Butir Soal}

Pengujian reliabilitas butir soal menggunakan AnatestV4. Dari hasil perhitungan diperoleh nilai tes sebesar 0,281 berada pada kategori rendah. Pada pengujian ini ada 1 soal yang valid tetapi tidak reliabel maka soal umtuk diuji adalah 10 saja.

\section{Pengujian Taraf Kesukaran Butir Soal}

Tabel 2. Hasil Taraf Kesukaran Butir Soal

\begin{tabular}{ccc}
\hline Interprestasi & Jumlah Item Soal & Nomor Item Soal \\
\hline Sangat Mudah & 8 & $10,11,13,17,23,25,30,31$ \\
Mudah & 8 & $1,2,3,5,7,12,16,18$ \\
Sedang & 5 & $6,20,24,27,28$ \\
Sukar & 7 & $4,8,9,14,15,21,33$ \\
Sangat Sukar & 6 & $22,26,29,32,34,35$ \\
\hline
\end{tabular}

Berdasarkan hasil analisis dari 35 butir soal diperoleh 8 butir soal yang memiliki tingkat kesukaran sangat mudah, 8 butir soal yang memiliki tingkat kesukaran mudah, 5 butir soal yang memiliki tingkat kesukaran sedang, 8 butir soal yang memiliki tingkat kesukaran sukar, dan 6 butir soal yang memiliki tingkat kesukaran sangat sukar.

\section{Pengujian Daya Pembeda Butir Soal}

Tabel 3. Data Hasil Daya Pembeda Soal

\begin{tabular}{ccc}
\hline Interprestasi & $\begin{array}{c}\text { Jumlah Item } \\
\text { Soal }\end{array}$ & Nomor Item Soal \\
\hline Jelek & 16 & $1,4,5,7,10,12,14,15,17,19,23,24,26,32,33,34$ \\
Cukup & 9 & $3,6,11,16,21,27,28,29,30$ \\
Baik & 5 & $9,13,16,20,25$ \\
Dibuang & 5 & $2,18,22,31,35$ \\
\hline
\end{tabular}

Hasil analisis dari uji daya pembeda butir tes diperoleh 16 butir yang berkualifikasi jelek, 9 butir yang berkualifikasi cukup, 5 butir yang berkualifikasi baik, dan 5 butir yang harus di buang (daftar lengkap dapat dilihat pada lampiran). Dari hasil uji coba yang dilakukan, dapat disimpulkan dari 35 item soal uji coba, hanya dipilih 10 item soal yang memenuhi syarat uji dan layak untuk digunakan sebagai instrument penelitian yaitu soal nomor 1, 3, 6, 9, 13, 16, 20, 28, 29, dan 30 .

Data hasil belajar dianalisis untuk mengetahui perbandingan penerapan yang digunakan. Data hasil belajar diperoleh dari selisih nilai dari pretest dan posttest siswa kelas XI IA.

Tabel 4. Data peningkatan

Kelas Eksperimen I $\quad$ Kelas Eksperimen II 


\begin{tabular}{ccc}
\hline Jumlah Sampel & 25 & 26 \\
Skor Minimum & -1 & 0,8 \\
Skor Maksimum & 1 & -1 \\
Rata-rata & 0,31 & 0,21 \\
\hline
\end{tabular}

5. Uji Normalitas Pretest

Tabel 5. Hasil Uji Normalitas

\begin{tabular}{|c|c|c|c|c|}
\hline Kelas & $\mathbf{N}$ & Sig & $\mathbf{0 , 0 5}$ & Kesimpulan \\
\hline Eksperimen I & 25 & 0,007 & & Berdistribusi Tidak Normal \\
\hline Eksperimen II & 26 & 0,033 & & Berdistribusi Tidak Normal \\
\hline
\end{tabular}

Uji normalitas dilakukan menggunakan uji liliefors dengan aplikasi spss, diperoleh nilai signifikan hasil belajar kelas eksperimen I adalah 0,007. Hal ini berarti, nilai signifikan kelas eksperimen I lebih kecil dari 0,05 sehingga data hasil belajar kelas eksperimen I berdistribusi tidak normal.Sedangkan, nilai signifikan hasil belajar kelompok eksperimen II adalah 0,033. Hal ini berarti nilai signifikan kelas eksperimen II lebih kecil dari 0,05 sehingga data hasil belajar kelas eksperimen II berdistribusi tidak normal.

\section{Uji Normalitas Posstest}

Uji normalitas dilakukan pada hasil posttest pada kelas eksperimen I dan kelas eksperimen II untuk mengetahui apakah data tersebut berdistribusi normal atau tidak. Hasil uji normalitas kelas eksperimen I dan kelas eksperimen II dapat lihat pada tabel 6.

Tabel 6. Hasil Uji Normalitas

\begin{tabular}{|c|c|c|c|c|}
\hline Kelas & $\mathbf{N}$ & Sig & $\mathbf{0 , 0 5}$ & Kesimpulan \\
\hline Eksperimen I & 25 & 0,007 & & Berdistribusi Tidak Normal \\
\hline Eksperimen II & 26 & 0,033 & & Berdistribusi Tidak Normal \\
\hline
\end{tabular}

Uji normalitas dilakukan menggunakan uji liliefors dengan aplikasi spss, diperoleh nilai signifikan hasil belajar kelas eksperimen I adalah 0,007. Hal ini berarti, nilai signifikan kelas eksperimen I lebih kecil dari 0,05 sehingga data hasil belajar kelas eksperimen I berdistribusi tidak normal.Sedangkan, nilai signifikan hasil belajar kelompok eksperimen II adalah 0,033. Hal ini berarti nilai signifikan kelas eksperimen II lebih kecil dari 0,05 sehingga data hasil belajar kelas eksperimen II berdistribusi tidak normal.

\section{Uji Homogenitas pretest}

Hasil posttest kelas eksperimen I dan kelas eksperimen II selanjutnya dilakukan uji homogenitas untuk mengetahui apakah data memiliki varians yang sama atau tidak. Hasil uji homogenitas untuk kelas eksperimen I dan kelas eksperimen II dilihat pada tabel 7.

Tabel 7. Uji homogenitas pretest

\begin{tabular}{|c|c|c|c|c|}
\hline Kelas & $\mathbf{n}$ & sig & 0,05 & Keterangan \\
\hline Eksperimen I & 25 & 0,47 & & homogen \\
\hline
\end{tabular}




\begin{tabular}{ll}
\hline Eksperimen II & 26 \\
\hline
\end{tabular}

Berdasarkan tabel 4.11 diketahui data homogenitas semua kelas eksperimen I dan eksperimen II nilai signifikasi < 0,05. Hal ini menunjukkan bahwa data hasil belajar kimia pada kelas tersebut memiliki data yang homogen.

8. Uji Homogenitas Posttest

Hasil posttest kelas eksperimen I dan kelas eksperimen II selanjutnya dilakukan uji homogenitas untuk mengetahui apakah data memiliki varians yang sama atau tidak. Hasil uji homogenitas untuk kelas eksperimen I dan kelas eksperimen II dilihat pada tabel 8 .

Tabel 8. Uji homogenitas pretest

\begin{tabular}{|c|c|c|c|c|}
\hline Kelas & $\vec{n}$ & sig & 0,05 & Keterangan \\
\hline Eksperimen I & 25 & 0,47 & & homogen \\
\hline Eksperimen II & 26 & & & \\
\hline
\end{tabular}

Berdasarkan tabel 4.11 diketahui data homogenitas semua kelas eksperimen I dan eksperimen II nilai signifikasi < 0,05. Hal ini menunjukkan bahwa data hasil belajar kimia pada kelas tersebut memiliki data yang homogen.

9. Uji hipotesis

Tabel 9. Hasil Uji Data eksperimen I

\begin{tabular}{llllll}
\hline Nilai & n & mean & Sig & $\boldsymbol{\alpha}$ & Keterangan \\
\hline Pretest & 25 & 54 & 0,003 & 0,05 & H0 ditolak \\
Posttest & 25 & 72 & & & \\
\hline
\end{tabular}

Berdasarkan data di atas nilai sig nilai eksperimen I $0,003<0,005$, hal ini menunjukkan bahwa $\mathrm{H} 0$ di tolak dan Ha diterima. Terdapat perbedaan data nilai pretest dan nilai posttest dari kelas eksperimen I. Dengan demikian terdapat perbedaan signifikan pembelajaran sebelum dan sesudah digunakannya strategi true or false.

Tabel 10. Hasil Uji Data Ekperimen II

\begin{tabular}{llllll}
\hline Nilai & n & mean & Sig & $\boldsymbol{\alpha}$ & Keterangan \\
\hline Pretest & 26 & 49,23 & 0,035 & 0,05 & H0 ditolak \\
Posttest & 26 & 63,85 & & & \\
\hline
\end{tabular}

Berdasarkan tabel 10 di atas nilai sig nilai eksperimen I 0,035 <0,005, hal ini menunjukkan bahwa $\mathrm{HO}$ di tolak dan Ha diterima. Terdapat perbedaan data nilai pretest dan nilai posttest dari kelas eksperimen II. Dengan demikian terdapat perbedaan signifikan pembelajaran sebelum dan sesudah digunakannya strategi take and give.

\section{Uji N-Gain}

Data peningkatan merupakan data yang diperoleh dari selisih antara hasil posttest dan pretest yang diperoleh siswa. Analisis data selanjutnya akan dilakukan terhadap data peningkatan (gain). Data yang didapat adalah sebagai berikut: 
Tabel 11. Hasil Uji N-Gain

\begin{tabular}{lll}
\hline Kelas & N-Gain & \% Gain \\
\hline Eksperimen I & 0,3059 & $30,59 \%$ \\
Eksperimen II & 0,2133 & $21,33 \%$ \\
\hline
\end{tabular}

Terlihat pada tabel 11, kelas eksperimen I lebih tinggi peningkatan $\mathrm{N}$-gain dengan angka 30,59\% dibandingka dengan peningkatan kelas eksperimen II.

Hasil nilai pretest kelas eksperimen I dan kelas eksperimen II dengan rata-rata secara berturut-turut yaitu 54 dan 49,23 dimana nilai tersebut masih banyak yang tidak mencapai ketuntasan. Hal ini disebabkan adanya faktor dalam diri dan dari lingkungan yang mempengaruhi belajar siswa, senada dengan pendapat Slameto dalam Mustikasari (2013) yang menyatakan salah satu faktor psikologis yaitu kecerdasan siswa dan faktor lingkungan sosial seperti peran guru.

Untuk mengetahui data hasil pretest termasuk kedalam data yang normal dan homogen dilakukan pengujian normalitas dan homogenitas. Uji normalitas data hasil pretest kelas eksperimen I didapatkan nilai signifikan sebesar 0,070>0,005 yang menunjukkan data nilai pretest kelas eksperimen berdistribusi normal sedangkan pada pretest kelas eksperimen II didapatkan nilai signifikan sebesar $0,000<0,005$ yang menunjukkan data nilai pretest kelas eksperimen II tidak berdistribusi normal. Uji homogenitas hasil pretest kelas eksperimen I dan II didapatkan nilai signifikan $0,332<0,05$ maka disimpulkan data pretest bersifat homogen.

Nilai rata-rata posttest pada kelas eksperimen I dan eksperimen II secara berurutan yaitu 72 dan 63,84. Data nilai posttest menunjukkan bahwa prestasi siswa meningkat dilihat melalui presentase jumlah siswa yang mencapai ketuntasan, untuk kelas eksperimen I yang menggunakan strategi true or false adalah $60 \%$ dengan jumlah siswa yang tuntas sebanyak 15 siswa dari 25 siswa, sedangkan pada kelas eksperimen II adalah 42,30\% dengan jumlah siswa yang tuntas sebanyak 11 siswa dari 26 siswa. Hal ini dikarenakan adanya perbedaan proses pembelajaran yang dilakukan antara kedua kelas, sehingga prestasi belajar siswa pad akelas eksperimen I dengan startegi true or false lebih tinggi dibandingkan kelas eksperimen II dengan strategi take and give.

Berdasarkan uji hipotesis yang dilakukan didapatkan hasil signifikan sebesar $0,003<0,05$ sehingga dapat diketahui bahwa H0 ditolak dan Ha di terima. Terdapat perbedaan data nilai pretest dan nilai posttest dari kelas eksperimen I. Dengan demikian terdapat perbedaan signifikan pembelajaran sebelum dan sesudah digunakannya strategi true or false. Begitu pula dengan uji hipotesis pada kelas eksperimen II didapatkan nilai signifikan $0,035<0,05$. Terdapat perbedaan data nilai pretest dan nilai posttest dari kelas eksperimen II dengan digunakannya strategi take and give. Dengan demikian disimpulkan prestasi belajar pada kelas eksperimen I lebih tinggi dibandingkan kelas eksperimen II namun keduanya sama-sama mengalami peningkatan hasil belajar. Hal ini juga dapat dilihat pada hasil uji N-Gain dimana kelas eksperimen I lebih tinggi dibanding dengan eksperimen II. Berdasarkan dari hasil penelitian diperoleh bahwa ratarata $\mathrm{N}$-Gain kedua kelas berada kualifikasi sedang(kelas eksperimen I) dan rendah (kelas eksperimen II). Dengan demikian dapat disimpulkan bahwa ada pengaruh strategi true or false dan take and give terhadap hasil belajar siswa SMA Negeri 1 Alalak tahun ajaran 2016/2017.

Beberapa faktor penyebabnya antara lain adalah interaktif yang intensif dari guru ke para siswa saat proses pembelajaran dengan strategi true or false dan take and give 
yang menyebabkan siswa merasa senang dan mudah dalam memahami pembelajaran. Pada umumnya strategi pembelajaran yang lebih melibatkan siswa akan meningkatkan hasil belajar siswa.

\section{PENUTUP}

Berdasarkan hasil penelitian dan pembahasan, maka simpulan dari penelitian ini adalah sebagai berikut; (1) Strategi pembelajaran True Or False dan Take And Give efektif dalam meningkatkan hasil belajar siswa SMA Negeri 1 Alalak pada materi Asam Basa. (2) Strategi True or False lebih efektif meningkatkan hasil belajar siswa dibandingkan dengan strategi Take and Give.

Berdasarkan hasil analisis data dan simpulan, maka peneliti memberikan saran untuk perbaikan pada penelitian yang akan datang antara lain; (1) Guru sebagai pendidik diharapkan mampu menjalankan peranan sebagai fasilitator, organisator, dan motivator bagi siswa sehingga keaktifan siswa dapat terbangun. (2) Didalam penggunaan strategi take and give akan menggunakan banyak waktu, karena dalam strategi ini siswa diminta memahami materi yang dia dapat dan siswa diminta menjelaskan kembali kepada teman yang lain. Sehingga perlu waktu yang lama dalam menjalankan startegi ini. (3) Untuk penelitian yang selanjutnya diharapkan peneliti mampu mengatur waktu dan kondisi keributan di dalam kelas agar proses pembelajaran lebih efektif.

\section{DAFTAR RUJUKAN}

Antika, R. N., Pramudiyanti, \& Yolida, B. (2013). Pengaruh Pembelajaran Kooperatif Tipe Take And Give Terhadap Hasil Belajar Siswa. Jurnal Bioterdidik: Wahana Ekspresi Ilmiah, 1(5), 1-11.

Arifah, A. N., Herdini, \& Copriady, J. (2012). Penerapan Strategi Pembelajaran Aktif Tipe True or False Untuk Meningkatkan Hasil Belajar Siswa Pada Pokok Bahasan Hidrokarbon di Kelas X SMA Negeri 6 Pekanbaru. Pekanbaru: Universitas Riau.

Majid, A. (2013). Strategi Pembelajaran. Bandung: PT Remaja Rosdakarya.

Mustikasari, S. (2013). Pengaruh Motivasi Belajar dan Perhatian Orang Tua Terhadap Prestasi Belajar Akuntansi Siswa Kelas X Kompetensi Keahlian Akuntansi SMK Negeri 9 Semarang Tahun 2012/2013. Semarang: Universitas Negeri Semarang.

Sardiman. (2011). Interaksi dan Motivasi Belajar Mengajar. Jakarta: Raja Grafindo Persada.

Silberman, M. (2011). Active Learning 101 Cara Belajar Siswa Aktif. Bandung: Nusa Media.

Sugiyono. (2012). Metode Penelitian Pendidikan: Pendekatan Kuantitatif, Kualitatif, dan $R \& D$. Bandung: Penerbit Alfabeta. 